\title{
9. Flat Bayreuth: A Genealogy of Opera as Screened ${ }^{1}$
}

\author{
Gundula Kreuzer
}

\begin{abstract}
Gundula Kreuzer challenges common assumptions about the 'screenification' of contemporary opera productions by reconsidering historical screening techniques within staged opera. Beginning with the Baroque picture-frame stage, she highlights how a desire for visual illusion on stage came into conflict with the increasingly complicated array of equipment, scenery, and props required to produce such elaborate scenes. Retracing strategies tested out at Wagner's Festspielhaus at Bayreuth, she argues that the theatre's curtain line came to imply an invisible screen with the capacity to organize the various media on the deep stage into a unified whole, a perception fostered by the visual and acoustic environment of the auditorium. Rather than a part of the telos of modernist painting, she highlights this flattened planar format as the outcome of technical and aesthetic conflict, whose legacy proves highly relevant to contemporary experiments with operatic staging.
\end{abstract}

Keywords: Auditorium, Stage, Architecture, Set Design, Richard Wagner, Music

Over the last several decades, music scholars have developed a keen interest in opera's relationship to the screen. A substantial number of essays and monographs have addressed such aspects of 'opera on screen' as studio productions of opera, TV relays or videos of live performances, television

1 This essay was developed in successive talks at Yale, Columbia, and Stanford Universities. Among the many stimulating audience responses, I am particularly indebted to Karol Berger, Craig Buckley, Kurt Forster, Brian Kane, and Carol Vernallis. Research has been generously supported by The Whitney and Betty MacMillan Center for International and Area Studies at Yale.

Buckley, C., R. Campe, F. Casetti (eds.), Screen Genealogies. From Optical Device to Environmental Medium. Amsterdam: Amsterdam University Press, 2019

DOI 10.5117/978946372900o_CHO9 
opera, opera films, or the diegetic use of opera in feature films. ${ }^{2}$ In this discourse, 'screen' often serves as a shorthand for all manner of cinematic media, which are contrasted to the seemingly independent phenomenon of opera: the screen tends to stand as the 'other' to live operatic performance. This ontological opposition has received ideological fuel since the introduction, in late 2006, of 'Live in HD' simulcasts by the Metropolitan Opera and other major opera houses. For many commentators, the fact that cinematic remediations now claim for themselves the thrill of a live event has heightened the sense of an underlying competition between stage and screen, along with the pervasive anxiety that our ubiquitous digital culture might render live performances obsolete or redundant. ${ }^{3}$ As music critic Anthony Tommasini does not tire of arguing, a simulcast of a performance enjoyed in the cinema offers an experience fundamentally different from all prior forms of remediated opera, because the simulcast combines audiovisual immersion with live communal viewing. Thus, Tommasini worries, HD broadcasts might not only lure audiences away from the opera house but also blur our sense of 'what the real thing is'. ${ }^{4}$ From this perspective, the silver screen appears as opera's harbinger of death.

Ironically, a number of film scholars have simultaneously raised concerns about the future of the cinema itself, which they see likewise endangered by what we might call the increasing 'screenification' of our world. ${ }^{5}$ Indeed, one could consider the very premise of this volume (namely, to rethink the genealogy of the screen) as an attempt to resituate the cinematic screen within an expanded - and ever-growing - panoply of screen practices. Yet with regard to opera, I would like to counter the widespread pessimism (or scepticism) toward its engagement with the screen, which I understand here very broadly as a two-dimensional 'information surface. ${ }^{6}$ Placing opera's relationship to such surfaces in a longer historical context challenges the frequently implied teleology of at least a partial medial succession from opera, via cinema, to digital content.

My essay is not the first, of course, to counter such linear narratives. Some scholars, for instance, have tended to stage competitions between

2 Thus the title of Marcia Citron's path-breaking monograph Opera on Screen. For select literature on opera on and for television, video, and live cinematic broadcasts, see Senici, 2010; Morris, 2010; Steichen, 2011; and Ward-Griffin, 2014.

3 The concept of remediation is taken from Bolter and Grusin, 1999. For a philosophical challenge to this opposition regarding opera films, see Cachopo, 2015.

4 Tommasini, 2013.

5 See, for instance, Friedberg, 2010; Elsaesser, 2016, p. 388.

6 This definition is from Huhtamo, 2004, p. 4. 
opera and cinematic media. A frequent claim is that simulcasts lack the key components defining the live operatic event, namely the co-presence of performers and spectators, and the productive relationships between them. ${ }^{7}$ One might also argue that opera-possibly more than film-has always been widely accessible outside the theatre via different media formats (whether as piano transcriptions or collector's cards), or that the cinematic challenge is not new to opera. As early as the 1920s, after all, the rise of film fanned what was widely discussed as an 'opera crisis' and spurred operatic productions to move away from the realism then newly associated with the cinema. Instead of such comparative arguments, however, I will explore features of the cinematic within opera, taking a media-archaeological perspective from which the relationship between opera and screening appears more complex than the predominant critical focus on opera's audiovisual remediations implies. First, screens are used not just to remediate opera but to mediate it in the first place: a variety of screens are essential to operatic production today. Second, I will propose that nineteenth-century illusionist staging practices themselves involved techniques of screening, which let the cinematic screen emerge less as a rival than as an ally of the proscenium stage. This historically and conceptually extended approach to screening as an operatic technique may, in the end, help reframe some recent developments in opera as well.

\section{Screens onstage}

To start with the obvious: video and computer screens have increasingly permeated opera houses since the rise of television. Monitors inside the proscenium and in the wings show a live feed of the conductor that affords onstage singers greater mobility, while additional live projections from the stage help stagehands, technical managers, and backstage singers to coordinate their activities. The continually increasing number of digitally operated props, lights, and stage technologies, meanwhile, require their own fleet of screens to manage. As tools for a performance, however, these screens are supposed to remain as invisible to audiences as the rehearsal process itself. By contrast, the visibility of supertitle screens - themselves initially contested technological additions to operatic performance-is by now deemed so essential as to influence price ranges in many an auditorium, even though supertitles are usually considered external to the 'actual' production. 
More controversial has been the use of projections in productions proper, whether as part of a set, as a means to simulate scenes that are difficult to mount with conventional stage technologies, or as commentary on the stage action. Although this now-common practice dates back at least to Erwin Piscator's theatre of the 1920s, some pundits have continued to bemoan the inclusion of cinematic projections onto suitable or specially designed surfaces on stage: at best, they hold, this wastes the theatre's own illusionist possibilities; at worst, it destroys them. ${ }^{8}$ As theatre scholar Arnold Aronson has argued perhaps most vocally, 'such projections and [moving] images draw upon a fundamentally different vocabulary from that of the stage', to the extent that 'the placement of such [film and video] technology on the stage is tantamount to carrying on a conversation in two languages'. ${ }^{9}$ Aronson reasons that the theatre is unique among representational art forms in that it deals 'with real surfaces and volumes. A floor that is treated to look like tile may in fact be made of wood, but it still functions as a floor'. ${ }^{10}$ Inserting projected images into this stage representation in most cases interrupts its continuity of space and time and thus dislocates the staged performance; even without a designated screen space, Aronson holds, a projected image infers its own frame within a stage production that is already framed by the proscenium. The presence of a projection and its implied screen thus collapses the basic representational tension between figure and ground into a hotchpotch of different media and materialities, each with 'different systems of reference'; as a result, 'content is overwhelmed by form'. ${ }^{11}$ Aronson's key concern, then, is the collapse of the 'space-time continuum' established by living bodies acting in the present moment with, in, and upon the three-dimensional space of a stage. ${ }^{12}$

Yet I would venture that this collapse is less inevitable than Aronson allows. One exception is a type of production that employs screens as part of the staged (twentieth- or twenty-first-century) reality itself. Take, for example, Mariusz Trelińsky's updated 2016 staging of Richard Wagner's Tristan und Isolde (1865), a much-discussed co-production of the Festspielhaus Baden-Baden, the Polish National Opera, the Metropolitan Opera New York, and the National Centre of Performing Arts in Beijing. ${ }^{13}$ (Figure 9.1)

8 On Piscator's use of screens and projections, see Fischer-Lichte, 1999, pp. 333-347.

9 Aronson, pp. 86-87.

10 Ibid., p. 87.

11 Ibid., pp. 93, 87.

12 Ibid., p. 88.

13 My discussion is based on my attendance at the Metropolitan Opera performance, conducted by Sir Simon Rattle, on 17 October 2016, as well as the HD broadcast of 8 October 2016, 


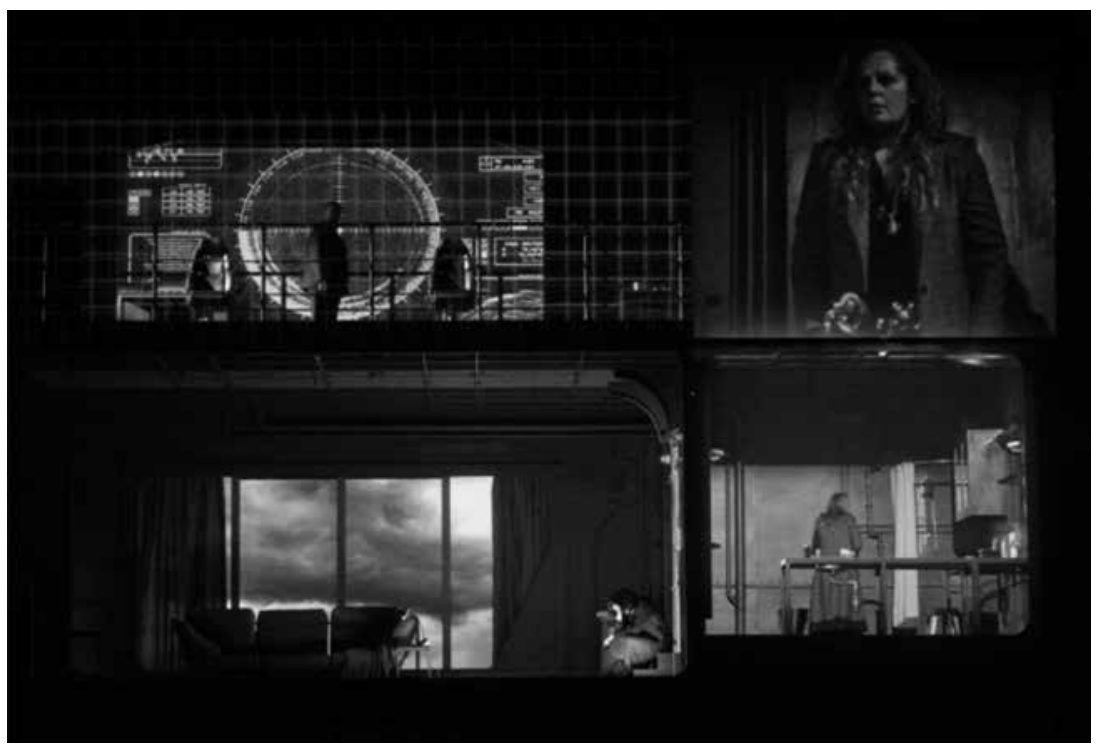

9.1: Tristan navigates his warship via radar control while spying on the distraught Isolde below deck with surveillance cameras in Mariusz Trelińsky's production of Richard Wagner's Tristan und Isolde, here at its premiere at the Baden-Baden Festspielhaus in March 2016. Courtesy of Monika Rittershaus.

In Act I, Isolde and Brangäne, the opera's only two female characters, are locked into the lower rooms of Tristan's modern-day warship, rendered as a vertically and horizontally split stage; and surveillance cameras project Isolde's actions live onto a screen on deck. Tristan alternately spies on these images and broods over an outsized digital radar screen. Distracting and crude these screens may be. But they efficiently communicate that Wagner's hero knows to navigate his ship but not his conscience. What is more, they drive home the misogyny at the core of Tristan's ill-fated enterprise - an attitude all too pervasive in our technologically advanced society, as the \#MeToo movement has since shown. Rather than break the theatrical illusion, Trelińsky's screens render his staging's contemporary, socio-critical flair in the first place.

Even more radical in its embrace of screen technology is Barrie Kosky's widely travelled production of Wolfgang Amadeus Mozart's Die Zauberflöte on Demand. 


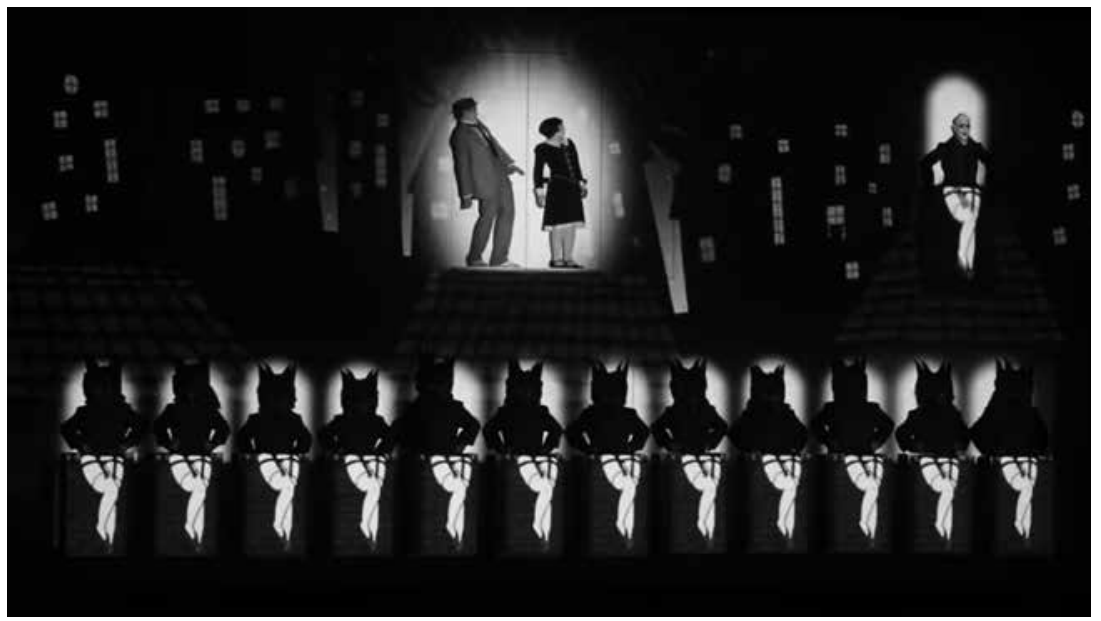

9.2: Having caught the fleeing Papageno and Pamina, Monostatos and his demonic aids start dancing with digitally animated legs in response to Papageno's magic bells in Barrie Kosky's 2012 production of Wolfgang Amadeus Mozart's Die Zauberflöte, here in a 2013 perormance of LA Opera. The soloists are strapped onto semicircular platforms in the upper half of the screen, while the chorus members stand in barrels right in front of the screen. Screen capture from digital video. https://www.youtube.com/watch?v=IS8mulLOK8

(1791), premiered at the Komische Oper Berlin in 2012. ${ }^{14}$ Counterintuitively for an opera, this staging aspires wholesale to silent film aesthetics. Kosky transplanted Mozart's work to the 1920s, and his only 'set' is a glossy white screen downstage onto which colourful animations are projected. Wearing stylized 1920s garb and mask-like makeup that recalls then-famous film characters, the singers emerge as needed through doors in the screen: they appear as though they were part of the animation, their bodies strapped onto small, rotating semi-circular platforms or stuck into a waist-high barrel downstage. (Figure 9.2) Moreover, the singers are usually whisked away as soon as they are done singing, because Emanuel Schikaneder's often clumsy and offensive spoken dialogues are here replaced by short filmic intertitles_-perhaps Kosky's most drastic intervention. In this production, then, projections and screens do not perforate Aronson's 'real-life' stage

14 The staging was co-produced by Suzanne Andrade of 1927 Productions Limited; for more details and the performance history, see http://www.19-27.co.uk/the-magic-flute/ (accessed 30 May 2018). My discussion is based on my attendance at the Opera Philadelphia performance on 15 September 2017. 
space; rather, human bodies intrude into an otherwise smooth visual animation.

This inversion raises a host of interesting questions related to audiovisual synchrony, human agency, and techno-determinism in operatic production (and beyond). For instance, the singers are unable to move their legs when fastened onto those platforms, and their limbs are animated by projections instead. (The Queen of the Night suffers the most extensive of such prostheses, with only the singer's head visible atop a monstrous digital spider.) Even during rare moments when-mostly male-characters move about in front of the screen, their gestures and steps are minutely choreographed in order to stay in sync with the ongoing projections: they are but cogs in the machine of filmic fantasy. In a way, each singer appears as the mere image of a character animated audiovisually through pre-conceived music and projections; the singers, that is, seem screened. Perhaps the only more daring - if practically easier-option would have been to disembody them entirely by having them sing in the pit or behind the screen, as was done in some early silent movie theatres.

Remarkably in the context of opera's relation to the screen, though, hardly any critics commented on the complete collapse of the threedimensional stage space. As soon as the production establishes its aesthetic as a self-conscious imitation of silent film, the frame of reference shifts from the opera house to the cinema. This shift makes the flatness of the stage representation as screen an expected (or at least accepted) feature rather than a disturbing intrusion into opera's typically material means of signification and a squandering of its theatrical space. Part of the staging's appeal, of course, is its very defiance of expectation, along with the way in which this new garb for Mozart's beloved warhorse creatively defuses at least some of the libretto's problematic aspects. But the tremendous success of this production and its unusually extended global tour make me wonder whether there is more to its approach than meets the cartoon-watching eye; whether the staging qua two-dimensional screening of Die Zauberflöte may have enthralled audiences not just because it is so visually alluring and dramatically consequential but also because it has something fundamental to say about the nature of staged opera. In the following sections I will therefore probe what the idea of screening might hold for the 'traditional' production of opera, first by looking into the rise of illusionist stage practices in the nineteenth century and then by zooming in on Wagner's Bayreuth theatre. 


\section{Illusionist opera's spatial dilemma}

To summarize historical developments rather coarsely: illusionist theatrical practices emerged in the late Renaissance and attached particularly to opera, with its elaborate machineries and audiovisual spectacle. Thus, it was above all opera that popularized across Europe what has tellingly been called the 'picture-frame stage': a designated and elevated stage framed by a proscenium arch and viewed mostly from the front (Figure 9.3), by contrast to thrust stages, theatres in the round, or performances in large halls or open spaces. ${ }^{15}$ On these proscenium stages, an opera's diegetic settings were simulated by painted backdrops plus a series of increasingly foreshortened pairs of flats and borders along the sides and the top of the stage, which enclosed the stage picture and hid the necessary machinery. In order to facilitate the stage's spatial illusion, the frontal positioning of at least an important part of the audience (and particularly the patron's central seat) allowed stage designers to translate perspectival painting, with its single vanishing point, from the flat canvas onto the stage. ${ }^{16}$ The resulting settings were tailored towards singers who mostly moved along a narrow strip downstage: this ensured both that the footlights would render them visible and that they would not destroy the illusion of the foreshortened sets when moving further upstage (although their integration was somewhat aided by the dimmer light towards the back). ${ }^{17}$ In a sense, Baroque opera had singers act in front of a spatial backdrop-or a voluminous surface framed by the proscenium arch.

The successive wings, flats, and drops were thus together intended to create the effect less of a real-world scene than of a well-executed painting thereofeven when, since the mid-eighteenth century, stage floors began to be raked and more complex calculations of spatial perspective liberated the sets from the central vanishing point. ${ }^{18}$ This pictorial model for Baroque productions is evinced also by theatrical terminology: the French and Italian terms for painted backdrops are identical with those for the painter's canvas (toile or tela), while

15 See Johnson, 2018.

16 Examples are the ground plans by Joseph Furttenbach of 1640, reproduced in Hewitt, pp. 195, 197. For surveys over the development and mechanics of Baroque operatic scenery, see Glixon and Glixon, 2006; Baker, 2013; and Johnson, 2018. The translation of perspective painting to the stage was not without its problems and worked perfectly only for a single point in the auditorium (typically the aristocratic patron's box); see Damisch, pp. 214-218.

17 See Baker, pp. 45-46.

18 On the latter development, associated above all with Ferdinando Galli-Bibiena's 1711 treatise L'architettura civile, see Baker, pp. 49-52. 


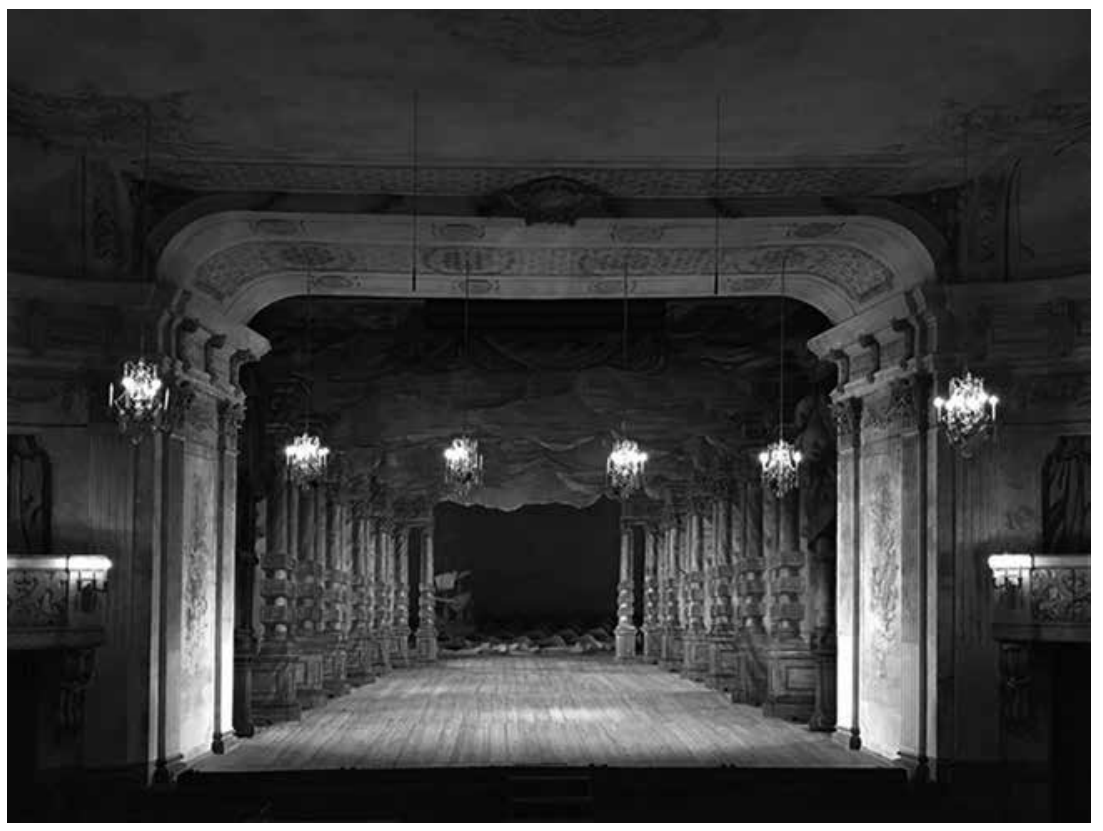

9.3: Carl Fredrik Adelcrantz, Drottningholm Slottsteater, near Stockholm, Sweden, 1762-1766. This unusually deep and pristinely preserved Baroque picture-frame stage is shown here with one of its original sets of seven wings and borders and, in the background, a seascape with wave machine. Photograph @ Gundula Kreuzer.

the German Prospekt specifically indicates a panoramic painting. ${ }^{19}$ (Only the British term backcloth and its American successor backdrop are generic to the theatre.) Vice versa, the painterly aspiration of stage designs manifested in their typical idealizing depictions. William Hogarth's famous painting of the climactic prison scene of John Gay's The Beggar's Opera (London, 1728), for example, renders the set as one continuous space rather than breaking it down into its individual drops and wings; only the painted curtain betrays the picture's inspiration in the theatre rather than in real life. (Figure 9.4) ${ }^{20}$

Within the proscenium frame, however, stage practices since the later eighteenth century moved towards less pictorial and ever more realistic means of representation. To name but a few well-known factors in this development, the Romantic fad for historical novels and a shift in operatic

19 See Grimm and Grimm, col. 2173; and Oxford English Dictionary. On the painterly model of Baroque stage design, see also Schivelbusch, pp. 192-193.

20 For the 1729 painting, see http://collections.britishart.yale.edu/vufind/Record/1669269 (accessed 31 May 2018). 


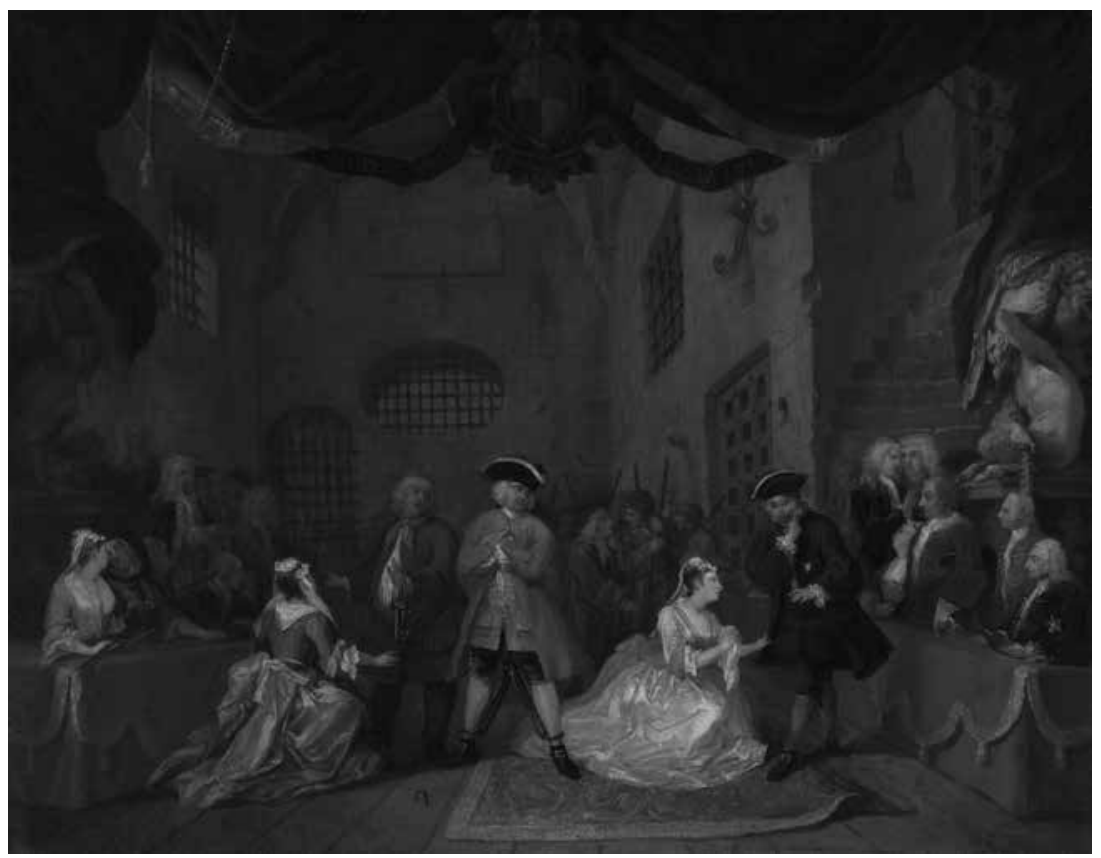

9.4: William Hogarth (1697-1764), The Beggar's Opera (1729). Oil on canvas, 59.1 x 76.2 $\mathrm{cm}$. Digital image courtesy of Yale Center for British Art.

subject matter from the generically mythological to the concretely historical called for more verisimilitude and characteristic detail in stage sets, while the rise of popular spectacular media such as panoramas, dioramas, and cycloramas further whetted audiences' visual appetite. ${ }^{21}$ At the same time, the increased strength of gas lighting (introduced in European opera houses between the 1810 s and the 1840 s) allowed singers to venture further from the stage front while revealing the flatness and artificiality of the painted sets. This exposure in turn aggravated dissatisfaction with the Baroque system's privileging of a few central seats in the auditorium, which for the majority of the audience left the spaces between wings visible. ${ }^{22}$ One result of all this was an increased use of practicable scenery, i.e. 'real' objects that singers could walk upon: wooden ledges, built stairs leading to painted houses, and

21 For more on the developments surveyed here, see e.g. Williams, pp. 58-75.

22 On the introduction of gas lighting on European stages, see Penzel, pp. 53-57; Baumann, 1988, pp. 81-114. On the growing dissatisfaction over the course of the eighteenth century with the undemocratic viewing conditions and unnatural vistas of Baroque stages, see Schivelbusch, pp. 191-199, 204-206. 
so on. These furthered a perceived realism not just of the respective settings but also of the acting, since singers now had voluminous scenescapes to engage with. In short, production techniques partially shifted from a series of two-dimensional representations to an assemblage of three-dimensional presentations of objects and scenery.

Yet this move had aesthetic and practical drawbacks. For one, the often heavy built scenery obstructed and eventually foiled quick mechanical changes of flats and drops between scenes, traditionally accomplished in full sight of the audience. Elaborate sets were now prepared upstage during an intimate (or so-called 'short') scene that was played in front of a drop hung further downstage; and where that proved impossible, act curtains or drops appeared in the early nineteenth century to cover the transformations, despite misgivings as to their disruption of the scenic illusion. ${ }^{23}$ More important in our context was what I might call the chief dilemma of nineteenth-century operatic practitioners: namely, how to reconcile the growing desire for visual illusionism with the proliferation of different media and materialities on stage, some of which were flat depictions of an intended object, others voluminous simulations, and yet others the 'real' thing. To evoke Aronson's terms, how could painted canvases, material structures, mechanical or living animals, real-life objects, coloured light, and costumed bodies be unified in such a way as to suggest a single frame of reference?

Although various architects, designers, directors, and composers individually addressed this issue in theory and practice, the person who has most come to epitomize the envisioned total theatrical illusionism is Richard Wagner (1813-1883). And for my purposes, Wagner offers once more a convenient port of call because his operas, his writings, and the Festspielhaus in Bayreuth all demonstrate an extreme commitment to smoothing over the interstices between his different participating media. One much-discussed way of doing so was to (try and) obscure each medium's technical and material conditioning — an aspiration notoriously critiqued by Theodor Adorno under the label of phantasmagoria. ${ }^{24}$ But another way, I argue, was to envision them all as contributing to the effect of a flat surface: that is, an animated and resonant painting.

Wagner's pictorial orientation operated on many levels. To begin with, illusionist painting played a key role in his seminal 1849 treatise 'The ArtWork of the Future'. Visually complementing singers and material objects, 
painted scenery was to deck out the rest of the stage with what Wagner called 'artistic truth' - the colours and appearances of nature. In return, the art of painting would be consummated in his Gesamtkunstwerk:

That which the landscape painter [...] has erstwhile forced into the narrow frames of panel-pictures - what he affixed to the egoist's secluded chamber walls, or offered for the random, incoherent and garbled stacking in a picture-storehouse [i.e. museum] — with this he will henceforth fill the ample framework of the tragic stage [...]. The illusion which his brush and finest blend of colours could only hint at and merely distantly approach, he will here bring to perfectly deceptive representation through the artistic use of every known device of optics and artistic lighting. ${ }^{25}$

In the expanded theatrical frame with its real light and living humans, Wagner expected painting to 'effect a livelier impression' and reach larger audiences. ${ }^{26}$ Indeed, the stage's enhanced affordances of simulation were the lure with which he hoped to attract the collaboration of visual artists (rather than 'mere' stage designers) in the first place. In a way, these artists did not merely provide the backdrop for the characters' actions; instead, singing bodies and coloured light became animating additions to their pictures. Practicable scenery notwithstanding, Wagner's theatrical vision remained as if painted: designs (or, more often, actual paintings) were translated from flat canvases to spatial models and then onto stage-where they were to achieve a heightened pictorial illusion.

Once again, theatrical jargon reveals that Wagner was not alone with this conception of the three-dimensional stage in terms of two-dimensional, painterly representation. Nineteenth-century German libretti began to subdivide acts not into scenes or Auftritte defined by the entrances and exits of characters, but into Bilder (pictures or images), defined by settings; while in France, popular shows promoted the equivalent term tableau. ${ }^{27}$ What is more, these theatrical practices resonated with discourses in the visual arts on how to achieve depth perception in painting and sculpture. In his influential 1893 treatise The Problem of Form in the Fine Arts, the sculptor

25 Wagner, 'Das Kunstwerk der Zukunft' (1849), in Wagner, 1911, vol. 3, p. 153. My translation is adapted from Wagner, 1966, vol. 1, pp. 186-187. As is evident from this quotation, Wagner was no fan of the visual arts per se.

26 Wagner, 'Das Kunstwerk der Zukunft', in Wagner, 1911, vol. 3, p. 153; translation in Wagner, 1966, vol. 1, p. 187 .

27 Pougin, p. 699. On the eighteenth-century rise of this 'tableau aesthetics', see Frantz, pp. 153-195. 
Adolf Hildebrand claimed that 'all spatial relations and all distinctions of form are read off from a single vantage point, so to speak, from front to back. [...] In artistic representation it is therefore a matter of setting in train this single, unifying movement into depth'. ${ }^{28}$ This unification was achieved by tending above all to what would be perceived as the first or frontal plane of the artwork: 'The more coherent and recognizable the surface effect of the object's image is, the more coherent is the idea of depth, for it is then stimulated by the depth relations between these two-dimensional units and not by the spatial values of the individual units that compose the image. ${ }^{29}$ In other words, even sculptors, who worked with homogenous voluminous materials (Hildebrand's chief interest was reliefs), were concerned with ordering their intended objects according to a unifying frame; and that frame was constituted by assuming the effect of a picture plane-by creating the impression as if the beholder were seeing a flat, continuous surface that only perfectly simulated depth.

Wagner's stage directions reveal the same preoccupation with achieving a coherent painterly surface. Already in his early operas he prescribed settings in painstaking detail, and he paid particular attention to audiovisual effects that not only use the full stage space but seek to extend it while keeping in perspective $3^{30}$ In the first act of Lohengrin (1850), for example, the challenge was to render the protracted mysterious arrival of the Grail knight from the far distance without breaking the perspective. According to an 1854 ground plan for this scene designed at the composer's behest by the Dresden actor Ferdinand Heine (Figure 9.5), as Patrick Carnegy has shown, Wagner had a boy in a miniature swan-boat pulled along a groove upstage before the identically clad Lohengrin singer entered further downstage, drawn by his 'real' swan (complete with movable neck and flapping wings). ${ }^{31}$ This substitution was possible — and all the more necessary—because Lohengrin does not sing during his journey, making both the excitedly commenting onstage observers and the offstage spectators focus exclusively on his visual arrival.

Elsewhere, Wagner followed French practices in using music to further the depth effects of explicitly painterly sets..$^{22}$ One instance is the opening

\footnotetext{
28 Hildebrand, p. 243 (emphases in original).

29 Ibid., p. 244.

30 On Wagner's particular penchant for subterranean and deep spaces, see Watkins, pp. 119-120.

31 See Carnegy, pp. 41-42.

32 Since the late eighteenth century, composers of French opera in particular sought to musically evoke their settings at the beginnings of acts; and they increasingly drew on diegetic offstage sound to enhance the emerging scene. A famous example is Fromental Halévy's Lajuive (1835),
} 


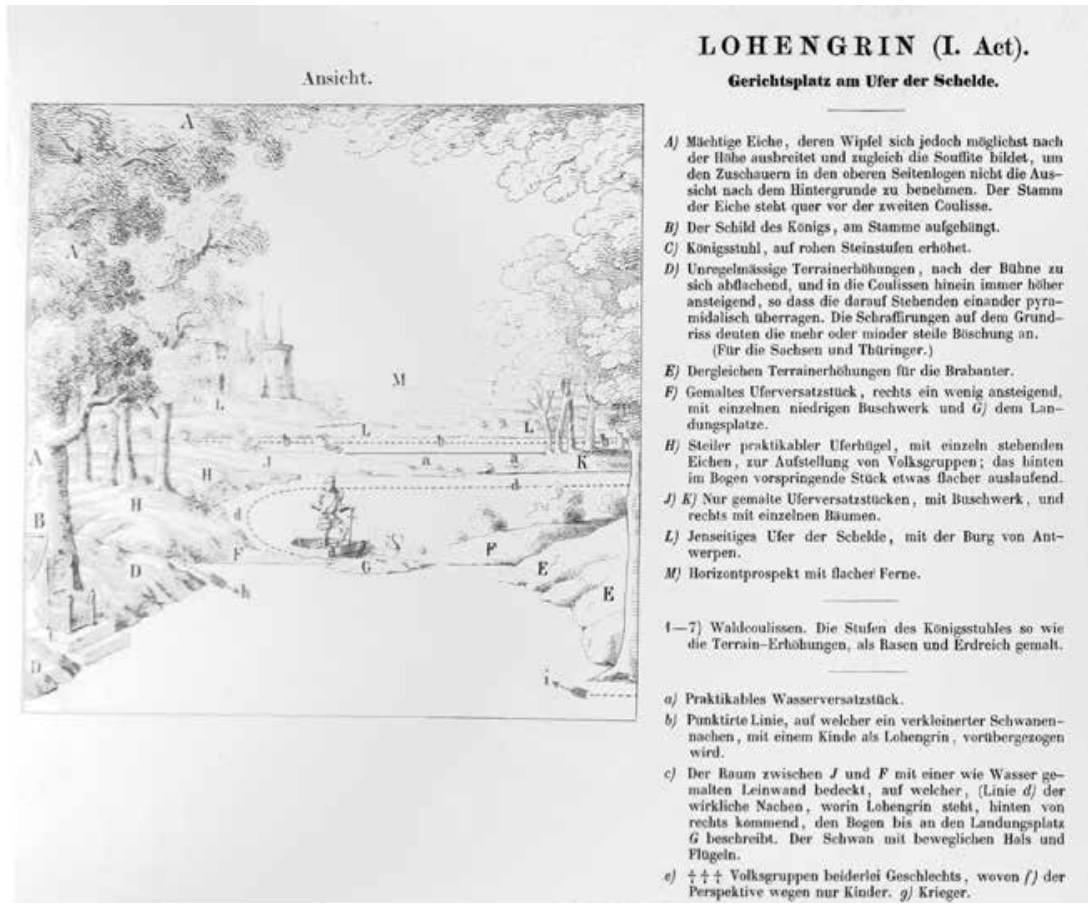

9.5: Ferdinand Heine (1798-1872), sketch-map of 1854 for Act I of Wagner's Lohengrin. Following Wagner's instructions, Lohengrin's arrival from the far distance is effected via a boy actor in a miniature boat moving along the dotted line $b$ (in red in the original) from left to right before the identically clad Lohengrin singer enters along the red line $\mathrm{d}$ on his "real" swan boat. Courtesy of Nationalarchiv der Richard-Wagner-Stiftung Bayreuth.

of Tannhäuser (1845), where Wagner described the Venusberg grotto as stretching into an unseeable distance. ${ }^{33}$ Accordingly, he called for irregular ledges and protruding rocks at various heights and distances that partly obscure the grotto's end and partly enable an increased foreshortening towards the back of the stage, thus facilitating the grotto's spatial simulation. The Venusberg's population was likewise staggered between the protagonists in the foreground and a host of mythical creatures frolicking mid- and upstage. And acoustically, Wagner evoked the grotto's expanse with an exceptionally long stretch of purely orchestral music following the curtain—music whose iridescent shimmering timbre and chromatically

whose curtain opened onto the intricate town square of medieval Constance, with an offstage organ and choral chanting seemingly emanating from its painted church.

33 Stage directions according to Wagner, 2001, p. 67. I have discussed the Venusberg scenes in more detail in Kreuzer, pp. 27-53, especially pp. 31-37. 
shifting sound fields evoke static (if sensually charged) space more than kinetic development. It takes about ninety seconds until we finally hear some singing (this is opera, after all); but it is only the gentle sirens' chorus sounding invisibly from afar - an effect that acoustically underscores the optical foreshortening, while making us wait another four minutes until the protagonists raise their voices. In his 1861 and 1875 revisions of the opera, Wagner further amplified the audiovisual stage setting to the point that his optical directions resemble a paint-by-number manual. ${ }^{34}$ Not accidentally, this Venusberg scene sparked what is perhaps the most substantial number of stand-alone paintings by non-theatrical artists of any operatic setting.

The conceptualization of operatic scenes as two-dimensional-if moving and sonorous - images also throws new light on Wagner's notorious open transformations. These lengthy transitions are accompanied (or, in fact, rendered) by explicitly illustrative music that sonically depicts the gradual change of locales, so as not to interrupt the theatrical illusion with a curtain or pause. Representing these transformations visually as well was crucial for Wagner's goal of total audiovisual synchrony, but it posed tremendous mechanical challenges. For the paradigmatic transition to Nibelheim's underground smithy in Das Rheingold (composed in 1853-1854 and premiered in 1869), a Bayreuth rehearsal score documented Wagner as desiring the following effect: "not "tableaux vivants"—but a "picture of life" shall unfurl everywhere before us.' ${ }^{35}$ His original German formulation ("nicht "lebende Bilder"-sondern ein "Bild des Lebens" soll sich überall vor uns entrollen') leaves no doubt about Wagner's technological conception, whereby one single image was to continually unroll before the spectators' eyes. This expression evokes moving canvases (Wandeldekorationen), a technology that had been reintroduced from the Baroque era into early nineteenth-century boulevard theatres and popular musical multimedia to emulate the spectacular optical entertainments of the time. In 1882, Wagner himself famously deployed such moving canvases in his premiere production of Parsifal for the horizontal Act I transformation from the meadow to the Grail temple, although his machinist Carl Brandt layered three open-worked canvases that moved at different speeds so as to better integrate the singers' simulation of walking through this painted landscape. ${ }^{36}$

34 See Wagner, 2001, pp. 7-10.

35 This comment was probably pencilled by Henriette Glasenapp into the vocal score owned by her husband, Wagner biographer Carl Friedrich Glasenapp, during the 1876 rehearsals; Nationalarchiv der Richard-Wagner-Stiftung Bayreuth, A-M 5153/I: Das Rheingold, p. 105.

36 On this transformation and for designs of the moving canvases, see Baumann, 1980, pp. 154165; and Carnegy, pp. 111-113. 
(Again we could speak of a deep surface; as with Kosky's screen, Wagner's protagonists became ornaments within the primarily technical optical animation of this scene.) Yet more significant than Wagner's future literal employment of this technology is that his allusion to it betrays once more a two-dimensional conception of spatial representation. Canvases can unroll horizontally or vertically, but they always move along the chosen plane and in a pre-ordered sequence. The analogy to film is obvious, although it rests on the technology of animating pictures (the unwinding of a canvas or film) more than on its visual affordances: for instance, montage techniques and sudden cuts run counter to Wagner's desired continual transformations. Instead, Wagner's concept of the single evolving Bild des Lebens points to a perceptual kinship with cinema: that of the flat surface facilitating life-like moving images - a surface akin to both the painter's canvas and the cinematic screen, whose material identity is rendered obvious in German, where Leinwand is the term for both. No wonder that Wagner frequently wrote of stagings as the 'scenic picture'. ${ }^{37}$

\section{Screening in Bayreuth}

Wagner's ideal that a staging ought to appear like an animated painting was fortified by some of the celebrated innovations of the Bayreuth Festspielhaus, built on his instructions (and incorporating earlier ideas of Gottfried Semper) by Otto Brückwald in 1872-1876. This two-dimensional approach may seem surprising: after all, the theatre's exposed high stage house widely heralded the spatial abilities of its cutting-edge illusionist technology. (Figure 9.6) Nevertheless, many commentators on the inaugural 1876 production of Wagner's Der Ring des Nibelungen admiringly noted its overall smooth picture quality. In comparison to conventional theatres, this effect was enhanced by a plethora of architectural features: the amphitheatrical seating (with its unobstructed sightlines), the row of protruding columns at the side walls narrowing in toward the stage, and the fan-shaped ceiling all directed the gaze to the stage, where two successive proscenia both enhanced the traditional framing function and seemingly further foreshortened the staged image, since the second proscenium was significantly smaller than

37 For instance Wagner, 'Das Bühnenfestspielhaus zu Bayreuth' (1873), in Wagner, 1911, vol. 9, p. 338 ('scenische Bild'); Wagner, 1966, vol. 5, p. 335. The analogy between continuous transformations and moving pictures would be famously enacted with Alban Berg's silent-film interlude for Lulu, premiered posthumously in 1937 . 


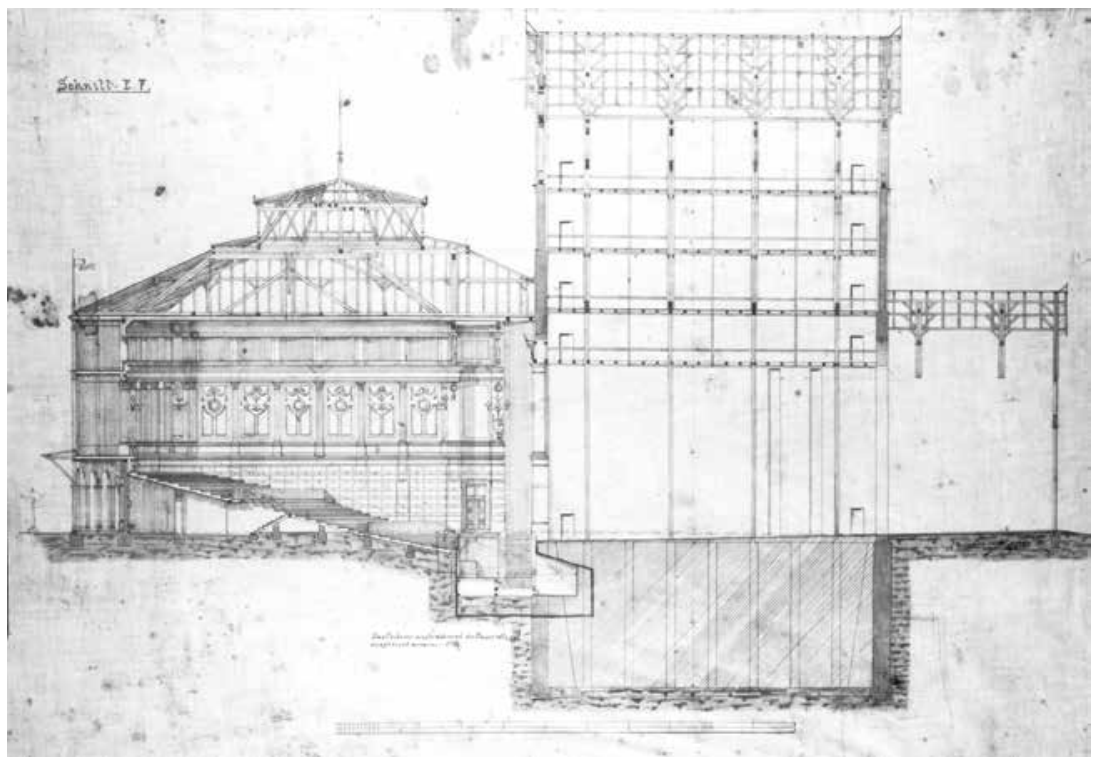

9.6: Longitudinal section of the Bayreuth Festspielhaus, constructed by Otto Brückwald (1841-1917) between 1872 and 1876. The plan shows the building before completion. Already notable are the high stage house and the lowered orchestra pit, although the latter proved too small and had to be significantly expanded in 1875 , as indicated in a first revision to the drawing (originally in red) by the construction supervisor Carl Runckwitz. Courtesy of Nationalarchiv der Richard-Wagner-Stiftung Bayreuth.

the first. (Figure 9.7) According to Wagner, Semper had anticipated that this proportion between the two proscenia would create 'the singular illusion of an apparent throwing-back of the scene itself, making the spectator imagine it quite far away, though he still beholds it in all the clearness of its actual proximity'. As with popular optical media such as panoramas, moreover, the actual distance of the stage was veiled by the fact that, in Wagner's words, 'between [the audience] and the picture to be looked at there is nothing plainly visible, merely a floating atmosphere of distance, resulting from the architectural adjustment of the two proscenia; whereby the scene is removed as it were to the unapproachable world of dreams. ${ }^{8}{ }^{8}$ The then-unusual (and originally accidental) total darkness of the auditorium further helped to ensure that spectators could look at nothing but this image emerging like 


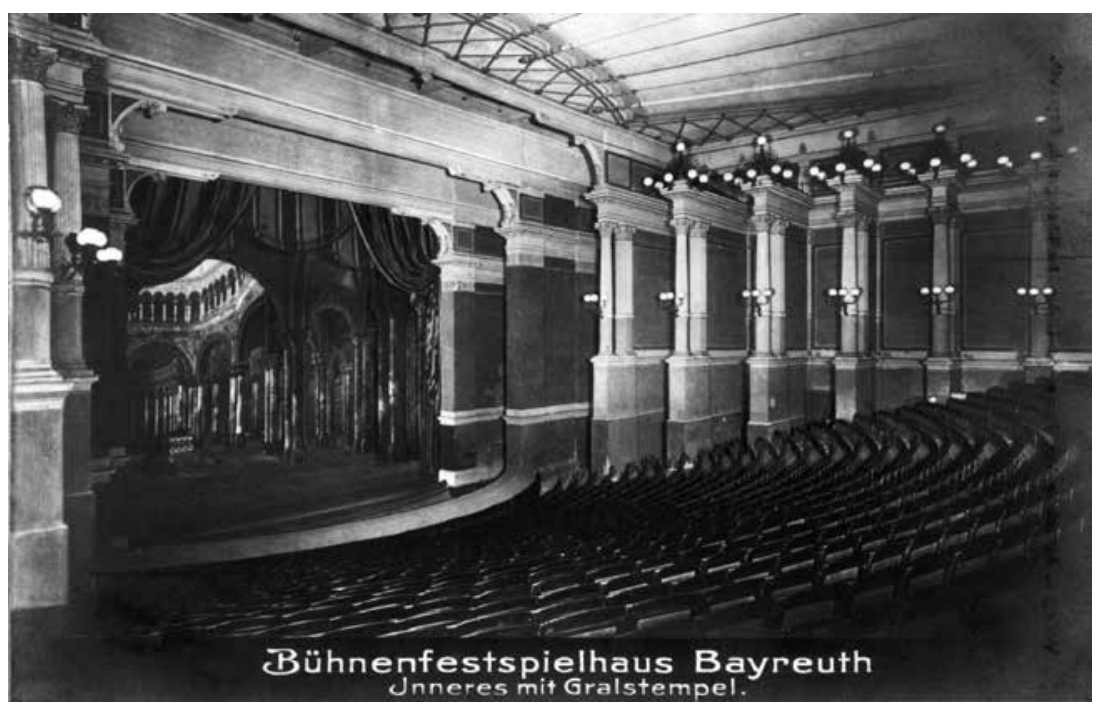

9.7: View from the side of the auditorium to the stage of the Bayreuth Festspielhaus, showing the 1882 Grail Temple set for Wagner's Parsifal and the striped curtain. Courtesy of Nationalarchiv der Richard-Wagner-Stiftung Bayreuth.

a dream out of obscurity - an effect that art historians have long related to the cinematic dispositif. 39

To be sure, Wagner was not the first to ponder architectural changes that might increase the theatre's overall illusionism. Already in the early nineteenth century, to cite but two examples, both the French colonel and inventor Jacques-François-Louis Grobert and the Prussian painter and architect Karl Friedrich Schinkel independently suggested removing the orchestra from sight, dimming auditorium lighting, and abolishing boxes in the proscenium wall and seats for patrons on the sides of the stage, all to enhance the theatre's effect of perspectival illusion..$^{40}$ Yet the Bayreuth Festspielhaus was the first opera house to realize such ideas comprehensively. And I want to suggest that its structural means to focus the gaze on the

39 See, for instance, Crary, 2002, p. 19; and Elcott, 2016, p. 51. See also ibid., pp. 54-57, on the enhanced picture quality due to the dual proscenium and darkness.

40 Among other proto-Wagnerian measures, Grobert proposed an amphitheatrical auditorium and advocated moving both prompters and orchestra into the wings on both sides of the stage. Grobert, pp. 227-29, 255-57, 271-72. On Schinkel, who also replaced the Baroque wing-and-fly scenery at Berlin's Nationaltheater with symbolic cycloramic backdrops that allowed for wider viewing angles while depending less on perspectival foreshortening, see Bomberger, 1998, pp. 148-151; and Forster, 2018, pp. 260-277. For earlier theatrical reformers such as the architect Louis Catel, see Biermann, 1928. 
performance consciously flattened the transition from auditorium to stage, leaving the impression as if Wagner's 'scenic picture' was not enacted on a deep stage but mounted on an invisible wall right before the audience (see again Figure 9.7). Neither a substantial apron nor a prompter's box protruded from the stage; the footlights were well hidden; and both orchestra and conductor remained invisible, because instead of the customary pit, Wagner's sunken orchestra - what he called his 'mystic abyss' - left but a narrow gap between auditorium and stage, a slightly curved and barely visible line in the ground.${ }^{41}$ Thus, in Bayreuth, the Spiellinie or curtain line (the imaginary line downstage beyond which actors would not venture) fell almost in one with both the edge of the stage and the acoustic 'gulf'. Accordingly, some spectators appreciated that Wagner's singers never stepped in front of the curtain line, not even for curtain calls.

The curtain itself also participated in this flattening. Instead of the thencustomary red velvet, whose rich folds both evoke depth and attract the eye, Bayreuth's curtain featured stripes; thus it defied the impression of volume without vying for attention with the emerging stage, as did the occasional painted curtains representing allegorical scenes or settings related to the opera. To further deemphasize its presence, the Bayreuth curtain likely used the same brown-and-yellow hues as the interior décor. ${ }^{42}$ The curtain was made of a lightweight fabric that could move more speedily, and it utilized a new diagonal pull — the so-called Wagner-curtain mechanism — that opened the curtain gently from the middle and moved it simultaneously to the sides and up, rather than simply parting in the middle or being raised directly upwards. (Figure 9.8) As Yale's music instructor Gustave Stoeckel marvelled, this curtain left 'the impression that some unseen hands have moved it very gracefully out of sight' - which is to say that it eased the technologically mediated transition from auditorium to stage, from sound to vision, from the real to the diegetic world. ${ }^{43}$ Even the narrowing series of dual columns at the sides of the auditorium could be seen as a visual remnant of the Baroque paired flats leading towards a foreshortened backdrop; and

41 Wagner, 'Das Bühnenfestspielhaus zu Bayreuth' (1873), in Wagner, 1911, pp. 337-338; translation in Wagner, 1966, vol. 5, p. 334 .

42 The exact colours and the direction of the stripes remain unclear, since the curtain of the 1882 Parsifal production depicted in Figure 9.7 was likely not the original one. For more on the Bayreuth curtain, see Dombois, 2012; and Kreuzer, pp. 91-97. By 1867, Hermann Helmholtz had established that vertical stripes (as in Bayreuth's 1882 curtain) made a wall or square look taller, while horizontal stripes made it look wider, but neither direction implied a third dimension; see Thomson and Mikellidoju, 2011. On the tradition of painted curtains, see Bachler, 1972.

43 Stoeckel, 1877, p. 266. 


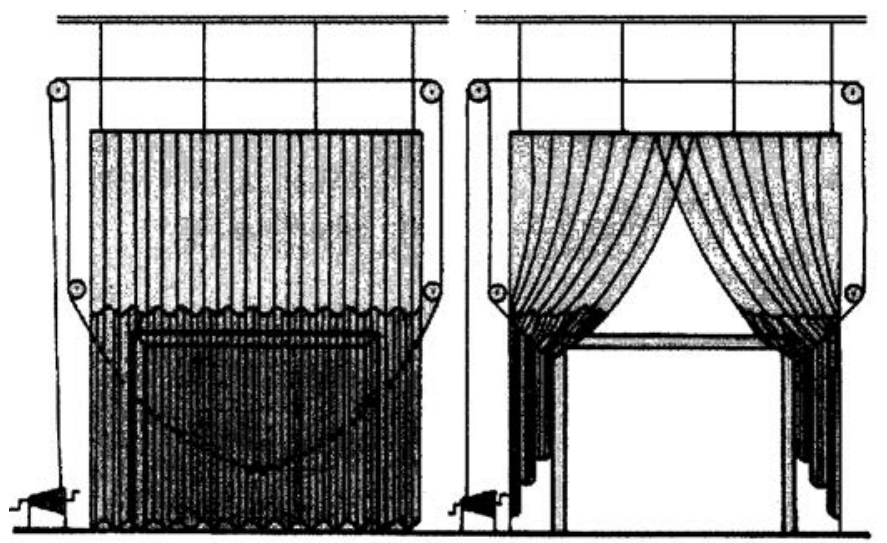

9.8: The curtain mechanism introduced in Bayreuth in 1876 and standardized as "Wagner curtain." Drawing by Walter Huneke, technical director of the Bayreuth Festival from 1966 to 1990 . By kind permission of the heirs of Walter Huneke.

they fostered the expectation that the opening of the proscenium contained a painted (if lively) canvas.

This flattening effect of Bayreuth's technology of image production and perception had an important acoustic equivalent. In the festival theatre's covered pit, the orchestral sound was famously pre-mixed and then projected into the auditorium via what Wagner called an 'acoustic sounding board' (akustische Schallwand).44 (Figure 9.9) For audiences, the resulting sound obscures the exact position of individual instruments in the pit. Incidental noises of tone production were also filtered out (one of Wagner's dreams come true). Thus divested of both its spatial and mechanical origins, which is to say of its concrete sources, orchestral sound appears not only as disembodied but also as flattened-as deprived of the distance at which it is produced. It emanates instead from the same gulf that marks the curtain line. The Bayreuth auditorium complemented this flattened orchestral sound generation with a deepening of sound transmission, or what we might call its proto surround-sound effect: the unusually long reverberation seemed to envelop audiences acoustically, just like those pillars that extended the stage frame into the auditorium incorporated them spatially. According to a cognitive process Michel Chion has discussed for sound film as 'synchresis', the resulting acousmatic music whose source is obscured attaches more easily to the simultaneous visual scenes, boosting the perceived immersive

44 Wagner, 'Vorwort zur Herausgabe der Dichtung des Bühnenfestspieles Der Ring des Nibelungen' (1862), in Wagner, 1911, vol. 6, p. 276; translation adapted from Wagner, 1966, vol. 3, p. 277. 
realism of the audiovisual representation (particularly in the case of explicitly diegetic or illustrative musical passages, such as those at the opening of Tannhäuser). ${ }^{45}$ By projecting the sound into the auditorium and back onto the screen-like stage, in short, Bayreuth put into practice Wagner's ideal that the 'ghost-like music' inspire spectators to an 'enthusiastic state of clairvoyance' like the vapours rising from the Delphi oracle. ${ }^{46}$

Ironically, Wagner's emphasis on sound as a medium of immersion became a notorious object of critique. As Friedrich Nietzsche contended in his 1888 pamphlet The Case of Wagner, with the latter ' $[\mathrm{t}$ ] he color of the tone [des Klanges] is decisive; what it is that resounds is almost a matter of indifference'. Nietzsche took this observation as indicative of the alleged reign of style over thought in Wagner's works - in other words, of surface over depth: through an overwhelmingly sensual exterior, Nietzsche held, Wagner incited the nerves of his spectators and short-circuited their brains. In view of a long aesthetic tradition (particularly in German-language thinking) that valued hidden depth and its alleged meanings over outward façade, this verdict amounted to a profound devaluation of Wagner's artistry. ${ }^{47}$ Adorno, too, cited 'the primacy of harmonic and instrumental sound [Klang]' as the epitome of Wagner's 'magic delusion' (Blendwerk), which the philosopher famously defined as the 'occultation of production by the outward appearance of the product'..$^{8}$

Yet it is telling that Adorno (following Marx) chose as his metaphor for this musical illusionism the optical medium of the phantasmagoria. In this popular entertainment of the late eighteenth and early nineteenth century, the supporting devices (a laterna magica and screens) were for the first time masked by total darkness to let projections appear as 'real'. ${ }^{49}$ And it was precisely such an immersive deception via smooth surfaces that Wagner pursued visually. Clement Greenberg has famously described the 'ineluctable flatness' of the surface as the defining, unique condition of

45 Chion, 1994, especially p. 63.

46 Wagner, 'Das Bühnenfestspielhaus zu Bayreuth' (1873), in Wagner, 1911, vol. 9, p. 339. Translation modified from Wagner, 1966, vol. 5, p. 335. On the acoustic properties of the auditorium, with its reverberation (with audience attendance) of almost 1.6 seconds, see Clarke, p. 155 .

47 Nietzsche, p. 624. On the aesthetic value placed on the idea of depth and its related concepts of interiority, inwardness, and meaning in German musical aesthetics, see Watkins, pp. 1-8 and 22-50; on the tensions inherent in this focus on depth by a discipline that traditionally addresses artistic surfaces, see Shusterman, pp. 1-5.

48 Adorno, 1998, p. 82; translation from Adorno, 2005, p. 74.

49 On Adorno's recourse to the phantasmagoria and its implications, see Gunning, 2004. On earlier associations between Wagner and phantasmagoria, see Crary, 1999, p. 254; on the technological conditions of phantasmagoric illusions, see Elcott, 2016, pp. 46-49, 54-57. 


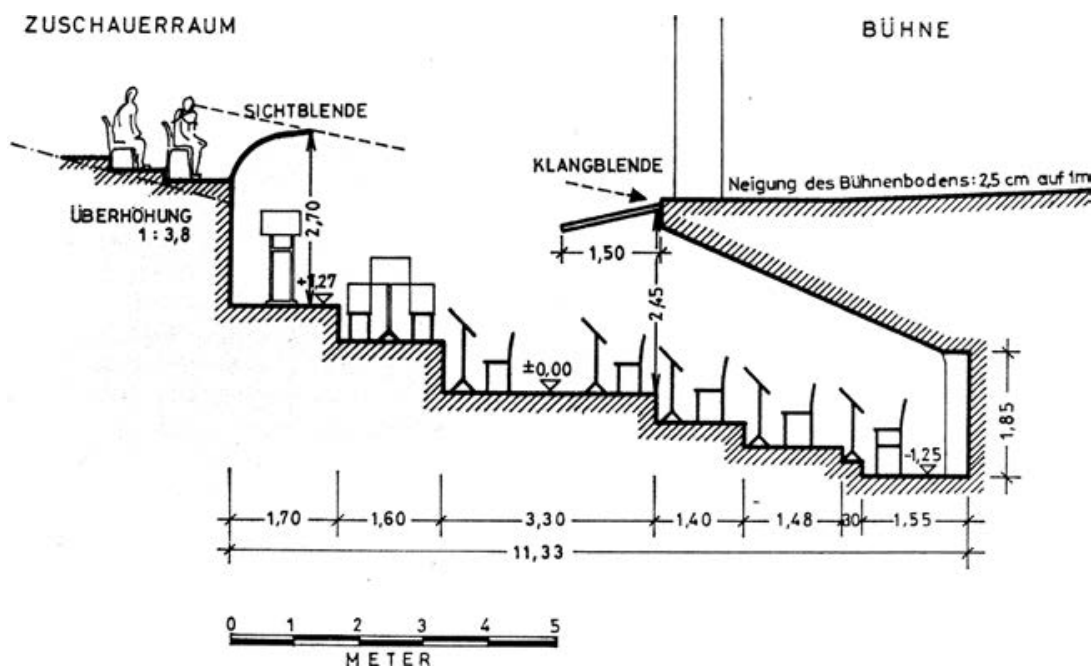

9.9: Longitudinal section of the sunken orchestra pit-Wagner's "mystic abyss" -in the Bayreuth Festspielhaus. Drawing by W. Rauda, 1953. Visible are the terraced seating for the orchestra (with strings atop and woodwind, brass, and percussion successively further below the stage), Wagner's "sounding board" extending from the front of the stage, and an additional curved screen that conceals the orchestral apparatus and its necessary lights. @ Nationalarchiv der Richard-Wagner-Stiftung, Bayreuth.

the art of painting, which otherwise shares with the theatre 'the enclosing shape of the support': until the twentieth century, painters generally worked to evoke three-dimensional spaces through this limit of the flat, framed canvas while simultaneously de-emphasizing its materiality. ${ }^{\circ}$ Vice versa, we could say that the specific, both delimiting and enabling condition of opera was the heterogeneity of its contributing media even on the purely visual level. Three-dimensionality was a given on the proscenium stage; but the challenge, as discussed, was how to meld everything into a unified perspective and thus create an illusionist overall appearance. Thus, if Aronson worried that onstage video projections might disrupt the diegetic space-time continuum, Wagner was concerned about any object (including bodies) protruding from his multimedia Gesamtkunstwerk and thereby exposing the entire staging as artifice. ${ }^{11}$ It is for this reason that his visual ideal remained that of the illusionist surface to which his stagings aspired.

The Bayreuth Ring production of 1876 occasionally emphasized this frontal plane literally, as with the partially transparent and painted scrim that 
covered the stage for the opening underwater scene or the clouds projected onto veils and gauzes. ${ }^{52}$ Even the Ride of the Valkyries was feigned at Wagner's request not with actual horses but with lantern slides projected onto the scenery, just as the composer had incorporated dissolving views in his 1861 and 1875 revisions of Tannhäuser. ${ }^{53}$ Regarding the seamless integration of his different onstage media, we have already witnessed Wagner's efforts to maintain an accurate perspective in the example of the boy actor simulating Lohengrin's faraway entrance. Another case in point was his unprecedented use of water vapours in the Ring to mask his stage technologies and amalgamate singers, practicable scenery, and flat canvases into a seemingly natural whole. ${ }^{54}$ Wagner's condensation of the space between auditorium and stage into a single thick line, I would propose, served the same purpose. As Sybille Krämer has argued, a line always implies a plane on which it is drawn; it 'is a medium of transmission and transgression. It homogenizes things that are different and thus mediates between heterogeneous worlds'.55 Bayreuth's visible curtain line-cum-gulf thus implied an invisible scrim or screen at the front of the stage through which the production was viewed and to which its multiple material elements adhered, as it were-just like the individual instruments' sounds gathered at the pit's acoustic baffle before being projected in toto to the audience, or like Hildebrand's frontal plane through which an artwork's depth was perceived.

A look at some of the pre-artistic (or pre-proto-cinematic) functions of screens in European culture fortifies this association of the curtain line with an implied vertical plane. Long before the rise in the late eighteenth century of optical media that employed flat surfaces for projections, a screen might serve (according to the editors of this volume) as 'a filter, a divide, a shelter, or a form of camouflage': it was used to partition spaces, to protect the inside from the outside, and to police migration across these demarcations. ${ }^{5}$ Among the earliest documented uses were screens against fire and drafts, with the term dating back to the fourteenth century. ${ }^{57}$ But the screen's function as screen always depended on its situatedness and its application in an individual context. By the same token, the theatre's invisible curtain line traditionally served to contain a performance spatiotemporally and to

53 On the Valkyrie projections (which left much to be desired), see Carnegy, p. 87; on the dissolving views Kreuzer, p. $3^{2}$.

54 On Wagner's use of steam and its many functions, see Kreuzer, pp. 165-188. 
separate it from the audience. These objectives were reinforced by Wagner materially, architecturally, and acoustically: in Bayreuth, the acoustic gulf doubled as nothing less than a screening technique-or a screen as cultural technique. According to Bernhard Siegert, 'cultural techniques are conceived of as operative chains that precede the media concepts they generate'. ${ }^{8}$ In this sense, the Bayreuth theatre's various techniques of flattening the performative surface do point forward towards the cinematic screen and its perceived visual illusionism. At the same time, however, they also reveal that nineteenth-century modes of perception were trained to see a representational surface as deep and a three-dimensional stage as flat-as an animated canvas. Cultivating these modes of perception was Wagner's ultimate means of veiling his stagings' technical origins. He sought to conceal not just the ropes and pulleys of individual stage technologies but the staged-ness of the performance itself, the entire pretence of stage production, to wit: the stage. Wagner's Bayreuth production could thus in fact be viewed like a living and sounding 'image of life' projected onto a wall right in front of the audience.

The notion of the proscenium's opening as an invisible wall would famously be popularized by proponents of naturalist theatre shortly after Wagner's death, with roots reaching back to mid-eighteenth-century discourses by Diderot and other philosophes. ${ }^{59}$ The implication here was that actors should behave as naturally as if they were enclosed by a solid fourth wall, which would become transparent only to audiences, not performers. Yet the aesthetics inherent in this fourth-wall naturalism and its prototypical setting of the indoor room are different from Wagner's. Rather than observing a seemingly real scene with its heterogeneous materialities (which also, of course, necessitates realistic settings), Wagner aspired to present an idealized nature, a higher sense of reality that would immerse and thereby change each spectator; hence also his mythic subjects and grand scenarios. His invisible wall served illusionism, not naturalism. It amounts to a pre-cinematic screen technique no less than those shadow projections, panoramas, and dioramas discussed as such by media scholars Charles Musser and Erkki Huhtamo. ${ }^{60}$

Tellingly, early cinematic practices themselves revealed their partial roots in opera's conflicted negotiation between two- and three-dimensional

$5^{8}$ Siegert, p. 11.

59 On naturalism and late nineteenth-century understandings of realism in theatre, see Fischer-Lichte, 1999, pp. 243-252; and Chothia, 2011; on the history of the concept of the fourth wall, see Lehmann, esp. pp. 57-155.

60 See Musser, 1984; Musser, 1990, pp. 15-54; Huhtamo, 2004; and Huhtamo, 2012. 
representations. This was the case not only when films were based on operatic plots, or when they were shown in actual opera houses or in otherwise darkened auditoria, with a curtain dramatically (un)covering the screen. As William Paul has demonstrated for American cinemas, the silver screen was also frequently placed upstage so as not to waste the depth of the stage and to evoke a Wagnerian sense of distance. It took acoustic arguments to move the fully flattened image to the front of the stage, eventually doing away with the stage altogether. ${ }^{61}$ Perhaps it was owing to this operatic genealogy of early cinema that critics so readily embraced Kosky's wholly screened Zauberflöte.

\section{Opera beyond the screen}

Against this background, we might re-evaluate recent pushbacks against the expanding use of screens in operatic (and theatrical) life. To take one example, in a 2017 advertising campaign for the Yale Repertory Theater, Meryl Streep addressed common concerns when she proclaimed that 'now, especially with all the competing screens that you can look at, there's just a real appetite for the actual as opposed to the virtual. And people are piling in to see live theater, to see something happen in front of them. ${ }^{62}$ Apart from the surprising notion that theatrical make-believe might be equated with 'the actual' (an idea itself conditioned by the digital age), Streep puts her finger on one possible — and frequently cited—distinguishing factor between cinematic screening and theatrical performance: that vibration of embodied presence, along with the possible synergy between spectators and actors. In doing this, however, Streep takes for granted the picture-frame stage and its intended frontal spectator. But if productions on such stages might themselves aspire to an aesthetic of screening (as they did in late nineteenth-century illusionist opera), their difference from cinema may not be as categorical as she assumes - at least in comparison to other forms of theatrical expression.

It might be precisely because of this illusionist family resemblance that, over the last decade, opera's increased 'screenification' has been paralleled

61 Paul, pp. 223-225, 237-238. Tellingly, the paradoxical relationship between the screen's flatness and its three-dimensional illusions was an important topic for early film theorists; for a short summary, see Friedberg, 2006, pp. 153-155.

62 Meryl Streep as quoted in a promotional email from the Yale Repertory Theater, 24 June 2017 . 
by —or has actually fostered—a less noted opposite trend: an upsurge of alternative opera companies that break with visually lush yet conceptually conservative productions and the frontal viewing position associated with both proscenium theatres and the cinema. Instead, they radically embrace opera's performative, material, experimental, collaborative, multimedial, and embodied roots. In New York, that cradle of HD broadcasts, companies like Loft Opera or On Site Opera proclaim already in their names their commitment to unusual performance spaces. And even upstart companies like Heartbeat Opera that perform in traditional studio theatres tend to liberate the performance from the box set and the orchestra from the pit.

Likely the most radical example of an opera without proscenium was staged in Fall 2015 by LA's The Industry, an 'independent, artist-driven' company founded in 2012. For performances of its so-called 'mobile opera' Hopscotch, it shuttled twenty-four groups of audience members in limousines simultaneously along three different routes to twenty-four performance sites across Los Angeles. ${ }^{63}$ Each route offered a different selection of eight ten-minute segments (or chapters), written by six teams of composers and librettists and performed by different sets of singers representing the three main characters at different stages of their story, with pre-selected parts of the cityscape turning into natural settings. All segments were continuously enacted and broadcast live to twenty-four screens at the production's 'Central Hub', a temporary tent-like structure located between the performance sites. Twelve additional chapters fleshed out the story through multimedia cartoons available only online. Screens and live performance, site-specificity and mobility, diegesis and reality, online content and embodiment, mediation and presence, nature and culture and technology all merged geographically, experientially, and conceptually.

Tellingly, the show's director, Yuval Sharon, explicitly declared his resistance to 'an old-fashioned assumption that theater should share classical painting's focus on a fixed perspective, or the ultra-controlled visual frame of the film [... which] infantilizes the audience and reduces their perception' ${ }^{64}$ Along with this illusionist perspective and confined theatrical space, Sharon shattered the traditional identification of performers and characters, fragmented both storyline and audience experience, and abandoned the idea of a singular composer, while the small and flexible orchestration allowed rare

63 The following discussion is based on press materials and reviews, the programme book and audio recording, and the online documentation at http://hopscotchopera.com/ (accessed 31 May 2018). Alex Ross described his experience of Hopscotch in Ross, 2015.

64 Sharon, p. 132. 
spatial suppleness for an opera. Obviously, the coordination and execution of the event crucially depended on digital media, whose influence we might also detect in the idea to serve up a selection of bite-sized fragments. At the same time, without an explicit stage area, Hopscotch's individual scenes depended all the more on the embodied audiovisual establishment of the performative situation in each location, be they abandoned skyscrapers, elevators, beaches, or the limousines themselves. When the MacArthur Foundation recognized Sharon in 2017 for 'expanding how opera is performed and experienced through immersive, multisensory and mobile productions that are infusing a new vitality into the genre', it acknowledged the opportunity he had seized for twenty-first-century opera at large. ${ }^{65}$

Ours, of course, is not the first era in which the rise or proliferation of screened media has challenged the proscenium theatre's illusionist interface and its predominantly passive mode of perception. Walter Benjamin, for one, believed that cinema and radio had rendered the entire operatic apparatus 'obsolete' and had stimulated Brecht's epic theatre reform instead. ${ }^{66}$ Aided by digital technologies and a resulting increase of kinesis in both spectators and performers, however, recent explorations of site-specific opera performances have developed new ways to challenge the screen (painted, animated, or implied) as the default model for immersive musical multimedia. Unlike film, in short, opera does not necessarily have to be screened, whether inside or outside the opera house. And, along with the liveness Streep praised, it may be this newfound mobility of performances, audiences, and works as well as the concomitant embrace of opera's mixed media that will support its deliverance from the screen.

\section{Works Cited}

Adorno, Theodor. 'Versuch über Wagner.' In Die musikalischen Monographien, pp. 7-148. Volume 13 of Gesammelte Schriften, edited by Rolf Tiedemann. Darmstadt: Wissenschaftliche Buchgesellschaft, 1998.

- - In Search of Wagner. Translated by Rodney Livingstone. London: Verso, 2005. Aronson, Arnold. 'Can Theater and Media Speak the Same Language?' In Looking into the Abyss: Essays on Scenography, pp. 86-96. Ann Arbor: University of Michigan Press, 2005.

65 Tom Huizenga and Robert Siegel on NPR's All Things Considered, 2017.

66 Benjamin, pp. $1,6$. 
Baker, Evan. From the Score to the Stage: An Illustrated History of Continental Opera Production and Staging. Chicago and London: University of Chicago Press, 2013. Benjamin, Walter. Understanding Brecht. Translated by Anna Bostock. Introduction by Stanley Mitchell. London and New York: Verso, 1998.

Baumann, Carl-Friedrich. Bühnentechnik im Festspielhaus Bayreuth. Munich: Prestel, 1980.

_—. Licht im Theater: Von der Argand-Lampe bis zum Glühlampen-Scheinwerfer. Stuttgart: Franz Steiner, 1988.

Biermann, Franz Benedikt. Die Pläne für Reform des Theaterbaues bei KarlFriedrich Schinkel und Gottfried Semper. Berlin: Gesellschaft für Theatergeschichte, 1928.

Bolter, J. David and Richard Grusin. Remediation: Understanding New Media. Cambridge, MA: MIT Press, 1999.

Bomberger, E. Douglas. 'The Neues Schauspielhaus in Berlin and the Premiere of Carl Maria von Weber's Der Freischütz.' In Opera in Context: Essays on the Historical Staging from the Late Renaissance to the Time of Puccini, edited by Mark A. Radice, pp. 147-169. Portland, OR: Amadeus Press, 1998.

Cachopo, João Pedro. 'Opera’s Screen Metamorphosis: The Survival of a Genre or a Matter of Translation?' Opera Quarterly 30, no. 4 (2015): 315-329.

Carnegy, Patrick. Wagner and the Art of the Theatre. New Haven, CT: Yale University Press, 2006.

Chion, Michel. Audio-Vision: Sound on Screen. Translated by Claudia Gorbman. New York: Columbia University Press, 1994.

Chothia, Jean. '“Zero...Zero....and Zero”: Permeable Walls and Off-Stage Spaces.' In Thinking on Thresholds: The Poetics of Transitive Spaces, edited by Subha Mukherji, pp. 17-28. New York: Anthem Press, 2011.

Citron, Marcia. Opera on Screen. New Haven, CT: Yale University Press, 2000.

Clarke, Joseph. The Architectural Discourse of Reverberation, 1750-19oo. PhD Dissertation. Yale University, 2014.

Crary, Jonathan. Suspensions of Perception:Attention, Spectacle, and Modern Culture. Cambridge, MA: MIT Press, 1999.

- - ' 'Géricault, the Panorama, and Sites of Reality in the Early Nineteenth Century.' Grey Room 9 (2002): 5-25.

Damisch, Hubert. The Origin of Perspective. Translated by John Goodman. Cambridge, MA and London: MIT Press, 1994.

Dombois, Johanna. 'Das Auge, das sich wechselnd öffnet und schließt: Zur Szenographie des Wagner-Vorhangs.' In Richard Wagner und seine Medien: Für eine kritische Praxis des Musiktheaters, edited by Dombois and Richard Klein, pp. 87-110. Stuttgart: Klett-Cotta, 2012.

Elsaesser, Thomas. Film History as Media Archaeology: Tracking Digital Cinema. Amsterdam: Amsterdam University Press, 2016. 
Elcott, Noam. Artificial Darkness: An Obscure History of Modern Art and Media. Chicago and London: University of Chicago Press, 2016.

- — . 'The Phantasmagoric Dispositif: An Assembly of Bodies and Images in Real Time and Space.' Grey Room 62 (2016): 42-71.

Fischer-Lichte, Erika. Kurze Geschichte des deutschen Theaters. Second edition. Tübingen and Basel: Francke, 1999.

- - The Transformative Power of Performance: A New Aesthetics. Translated by Saskya Iris Jain. London and New York: Routledge, 2008.

Forster, Kurt W. Schinkel: A Meander Through His Life and Work. Basel: Birkhäuser, 2018.

Frantz, Pierre. L'esthétique du tableaux dans le théâtre du XVIIIe siècle. Paris: Presses Universitaires de France, 1998.

Friedberg, Anne. The Virtual Window: From Alberti to Microsoft. Cambridge, MA: MIT Press, 2006.

_—_. 'The End of Cinema: Multimedia and Technological Change' (200o). In The Film Theory Reader: Debates and Arguments, edited by Marc Furstenau, pp. 272-278. London and New York: Routledge, 2010.

Glixon, Beth and Jonathan Glixon. Inventing the Business of Opera: The Impresario and His World in Seventeenth-Century Venice. Oxford and New York: Oxford University Press, 2006.

Greenberg, Clement. 'Modernist Painting' (1960). Revised version in Esthetics Contemporary, edited by Richard Kostelanetz, pp. 198-206. Buffalo, NY: Prometheus Books, 1978.

Grimm, Jacob, and Wilhelm Grimm, eds. Deutsches Wörterbuch, 13:2173 ('Prospect, prospekt'). Leipzig: Hirzel, 1889.

Grobert, Jacques-François-Louis. De l'éxécution dramatique considérée dans ses rapports avec le matériel de la salle et de la scène. Paris: F. Schoell, 1809.

Gunning, Tom. 'Illusions Past and Future: The Phantasmagoria and its Specters.' MediaArtHistoriesArchive (2004). http://www.mediaarthistory.org/refresh/ Programmatic\%2okey\%2otexts/pdfs/Gunning.pdf. Accessed 31 May 2018.

Habel, Heinrich. Festspielhaus und Wahnfried: Geplante und ausgeführte Bauten Richard Wagners. Munich: Prestel, 1985.

Hewitt, Barnard, ed. The Renaissance Stage: Documents of Serlio, Sabbattini and Furttenbach. Coral Gables, FL: University of Miami Press, $195^{8}$.

Hildebrand, Adolf. 'The Problem of Form in the Fine Arts.' In Empathy, Form, and Space: Problems in German Aesthetics, 1873-1893, introduction and translation by Harry Francis Mallgrave and Eleftherios Ikonomou, pp. 227-279. Santa Monica, CA: Getty Center for the History of Art and the Humanities, 1994.

Huhtamo, Erkki. 'Elements of Screenology: Toward an Archaeology of the Screen.' ICONICS: International Studies of the Modern Image 7 (2004): 31-82. 
. 'Screen Tests: Why Do We Need an Archaeology of the Screen?' Cinema Journal 51, no. 2 (Winter 2012): 144-148.

Huizenga, Tom, and Robert Siegel. 'Opera Director Yuval Sharon Awarded MacArthur “Genius” Grant.' All Things Considered, WNPR, 11 October 2017. http://www. npr.org/sections/deceptivecadence/2017/10/11/556899374/opera-director-yuvalsharon-awarded-macarthur-genius-grant. Accessed 31 May 2018.

Johnson, Eugene J. Inventing the Opera House: Theater Architecture in Renaissance and Baroque Italy. Cambridge, UK: Cambridge University Press, 2018.

Krämer, Sybille. 'Graphism and Flatness: The Line as Mediator between Time and Space, Intuition and Concept.' In The Power of Line: Linea III, edited by Marcia Faietti and Gerhard Wolf, pp. 10-17. Munich: Hirner, 2015.

Kreuzer, Gundula. Curtain, Gong, Steam: Wagnerian Technologies of NineteenthCentury Opera. Oakland, CA: University of California Press, 2018.

Lehmann, Johannes Friedrich. Der Blick durch die Wand: Zur Geschichte des Theaterzuschauers und des Visuellen bei Diderot und Lessing. Freiburg: Rombach, 2000. Morris, Christopher. 'Digital Diva: Opera on Video.' Opera Quarterly 26, no. 1 (2010): 96-119.

Musser, Charles. 'Toward a History of Screen Practice.' Quarterly Review of Film Studies 9, no. 1 (1984): 59-69.

——. The Emergence of Cinema: The American Screen to 1907. New York: Scribner, 1990.

Nietzsche, Friedrich. 'The Case of Wagner.' In Basic Writings of Nietzsche, edited by Walter Kaufman, pp. 6o1-654. New York: The Modern Library, 1968.

Oxford English Dictionary. 'Back-cloth $n$. 2' and 'back-drop.' http://www.oed.com. Accessed 21 June 2018.

Paul, William. When Movies Were Theater:Architecture, Exhibition, and the Evolution of American Film. New York: Columbia University Press, 2016.

Penzel, Frederick. Theatre Lighting Before Electricity. Middletown, CT: Wesleyan University Press, 1978.

Pougin, Arthur. Dictionnaire historique et pittoresque du théâtre et des arts qui s'y rattachent. Paris: Firmin-Didot, 1885.

Ross, Alex. 'Opera on Location: A High-Tech Work of Wagnerian Scale is being Staged Across Los Angeles.' The New Yorker, 16 November 2015. https://www. newyorker.com/magazine/2015/11/16/opera-on-location. Accessed 31 May 2018.

Schivelbusch, Wolfgang. Disenchanted Night: The Industrialization of Light in the Nineteenth Century. Translated by Angela Davies. Berkeley: University of California Press, 1988.

Senici, Emanuele. 'Porn Style? Space and Time in Live Opera Videos.' Opera Quarterly 26, no. 1 (2010): 63-8o.

Sharon, Yuval. 'A Dialogue [with Josh Raab] in Place of a Director's Note.' Hopscotch: A Mobile Opera [program book]. Los Angeles: The Industry, 2015. 
Shusterman, Richard. Surface and Depth:Dialectics of Criticism and Culture. Ithaca: Cornell University Press, 2002.

Siegert, Bernhard. Cultural Techniques: Grids, Filters, Doors, and Other Articulations of the Real. Translated by Geoffrey Winthrop-Young. New York: Fordham University Press, 2015.

Steichen, James. 'HD Opera: A Love/Hate Story.' Opera Quarterly 27, no. 4 (2011): 443-459.

Stoeckel, Gustave J. 'The Wagner Festival in Bayreuth,' New Englander 36, no. 139 (April 1877): 258-293.

Thompson, Peter, and Kyriaki Mikellidoju. 'Applying the Helmholtz Illusion to Fashion: Horizontal Stripes Won't Make You Look Fatter.' i-Perception 2 (2011). https://www.ncbi.nlm.nih.gov/pmc/articles/PMC3485773/. Accessed 31 May 2018. Tommasini, Anthony. 'A Success in HD, But at What Cost?' The New York Times, 14 March 2013. https://www.nytimes.com/2013/03/15/arts/music/mets-hdbroadcasts-success-but-at-what-cost.html. Accessed 31 May 2018.

Wagner, Richard. Sämtliche Schriften und Dichtungen. Volksausgabe. 16 vols. Leipzig: Breitkopf \& Härtel, 1911.

—_. Prose Works. Translated by William Ashton Ellis. 8 vols. New York: Broude Brothers, 1966.

——. Tannhäuser und der Sängerkrieg auf Wartburg: Textbuch der letzten Fassung mit Varianten der Partitur und der vorangehenden Fassungen, edited by Egon Voss. Stuttgart: Reclam, 2001.

Ward-Griffin, Danielle. 'Virtually There: Site-Specific Performance on Screen.' Opera Quarterly 30, no. 4 (2014): 362-368.

Watkins, Holly. Metaphors of Depth in German Musical Thought: From E.T.A. Hoffmann to Arnold Schoenberg. Cambridge, UK: Cambridge University Press, 2011. Williams, Simon. 'The Spectacle of the Past in Grand Opera.' In The Cambridge Companion to Grand Opera, edited by David Charlton, pp. 58-75. Cambridge, UK: Cambridge University Press, 2003.

\section{About the Author}

Gundula Kreuzer is professor of music at Yale University. Her research interests embrace the history and theory of opera, with a special focus on aspects of performance, staging, technology, mediality, and sound; music and politics; reception studies; and German and European cultural history since the late eighteenth century. Kreuzer is the author of the award-winning Verdi and the Germans: From Unification to the Third Reich (Cambridge University Press, 2010) and Curtain, Gong, Steam: Wagnerian Technologies 
of Nineteenth-Century Opera (University of California Press, 2018). Her editorial work includes the critical edition of Verdi's chamber music for The Works of Giuseppe Verdi (Chicago University Press, 2010) and service as reviews editor for Opera Quarterly. In 2019, she received the Dent Medal of the Royal Musical Association and launched the annual symposium Y | Opera | Studies Today (YOST). 